an ability to select deftly (often with almost uncanny intuition) those items worthy of Nature. He never tired. of discussing his plans and ambitions for the future, in which the tradition and the progress of Nature would be maintained without faltering.

In his inaugural address following his election to the Royal Society of Edinburgh in 1953 - of which he was justly proud-he stated that no material for publication in Nature came from the U.S.S.R. and only a little from its satellites. The trend in the early 'sixtios has been that material has flooded in for publication from the U.S.S.R and its satellites. This was part and parcel of his deliberate policy to encourage the submission of material from the Eastern bloc. Similarly, he concentrated on the advancement of the emergent countries, offering all the encouragement and help possible in publication.

Jack Brimble lived long enough for the journal to reach its 5,000th issue on August 28, 1965. That he was not ostentatious and was still proud of his West Country lineage and accent was obvious to all who saw his B.B.C.2 interview at this time.

Jack Brimble's life, which came to th close on November 15, was dodicated to the editorship of Nature; but he will be remembered by those scientists who knew him as a man even more than as an editor. His immediate impact was one of outgoing gaiety and genorosity of spirit. First there was a hearty greeting, puckishly provocative ("You don't seem to have published much lately !") and offered with a sincerity which made it evident that he revelled in talk and the company of friends. Then came the ebullient phase-his mind was always bubbling over with some question of the day-gossip about the scientifie world-shrewd and always entiroly free from maliceabout who ought to get this chair or that; who ought to 'have his head examined'; who ought to be put on this committeo; what ought to be done to improve the universities or the Research Councils or the British Association. So then to the third phase: what should Nature say about this? Has Nature drawn attention forcibly enough to this or that? Just beneath the scientific-man-abouttown was the keen editor, always on the alert for news, ideas, opinions; able even in his boisterous moments to catch hold of a point of view and to make sure (if he thought the view worth preserving) that it was included in that constant scanning of the scientific scene which was his life's work and which made Nature the most remarkable scientific journal of its class in the world.

He camo to look on the journal as being his life and always insisted that it belonged to the world of science.

\section{GRASSLAND AND FODDER IN INDIA}

\section{The Grassland and Fodder Resources of India}

By R. O. Whyte. Revised edition. (Scientific Monograph, No. 22.) Pp. $\mathrm{x}+553+58$ plates. (New Delhi: Indian Council of Agricultural Research, 1964.) Rs. 20.00.

WHIS revised edition of The Grassland and Fodder Resources of India follows that first printed in 1957 and deals exhaustively with fodder resource problems undor Indian conditions. Recommendations are made on a wide variety of production methods. The twenty chapters are devoted to fodder supplies in relation to the present-day needs of Indian livestock and to ways anc moans of attacking the almost insoluble problem of feeding too many cattle on too little grass and other feeds. Emphasis is on the need for better-quality fodders; those at prosont available aro extremely poor by any standard. Plant breeding, herbage, seed production and an account of Indian soils and their fertilizer requirements are dealt with in separate chapters. Problems of conservancy and the related ones of pasture management are considered fully, as also are details of the feeding régimes used on Government or corporation farms. These, however, are much above avorage and bear little relation to those used in the Indian villages. This is clearly reflected in the much higher levels of production attained on, say, the military farms of India. Although details of milk yields are not given, there is the clear suggestion that at their best, and when adequately fed, the Indian breeds of dairy cattle produce on a par with European cattle. Frequent mention is made of the potential output of a reshaped dairy industry in India, but it would have added to the value of the argument if precise figures of yield (per cow and per acre) could have been included.

Throughout the book is the continued theme which emphasizes the problem of fodder in India as one where the primary need is to reduce the number of cattle so as to bring it into lino with fodder supplies (actual and potential). Cattle are the backbone of Indian agriculture, and efficiency must be raised if prosperity is to come to rural India. Clearly nutrition is the key, but at present the cattle are underfed and hence the rather distressing (but realistic) call for reducing their numbers. However, there are religious problems which ultimately can only be solved by the Indian people themselves and this depends on the education of the masses. It is part of the Hindu philosophy to prohibit the killing of cattle, however worthless and however competitive with the human for food. This point bears repetition, even though it has always been the major concern of agricultural developers in India and is frequently repeated by those from other countries who visit the sub-continent.

A plea is made for more research and also for making available nation-wide statistics of sufficient accuracy on which sound rural planning can be based. In India, man, cattle, sheep, pigs and poultry are all in competition for too little food. The farms are too small, and even if it were possible to intensify production the problem would still romain; namely, how the cultivator with less than five acres can grow bread, corn and fodders sufficient to provide for his family, let alone produce a surplus. Part of this problem concerns levels of crop yield; the average cereal and pulse yields in India are about $600 \mathrm{lb}$. and $400 \mathrm{lb}$. per acre respectively; whereas on the Government farms, including the experimental and seed farms, these figures aro quadrupled. As with the animals, the key is partly nutritional; the usual story of a need for both organic and inorganic fertilizers, including, in $\operatorname{som} \theta$ cases, trace elements. At the present level of yield in all crops, the supply of animal feed provides less than one-fourth of the protein and two-fifths of the enorgy requirements of the bovino pcpulation.

Natural grasslands are infrequent on the Indian scene, but man-made 'grassland' occupies extremely large aroas and is basic for the nutrition of cattle and sheep. Many attempts have been made to classify these grazing lands and there is at present in progress tho Grassland Survey of India, in which the author of the monograph has taken a prominent part. Descriptive notes concerning a number of contrasting sites dealt with in the survey are givon in Chapter 7, while in the preceding chaptor a valuable record is made of botanical features of grassland in several regions. Most of these 'grasslands' represent interim (seral) stages between forest and desert; fow appear to be climax stages.

The book is well illustrated and has a useful bibliography. The glossary of Indian terms is indispensable for the reader outside India. The production is of reasonably good standard, but the text is not without its typographical errors. The volume should havo the interest of a wide audienco of pasture and animal scientists and is of particular importance to all who live in densely populated regions within the tropies. WILLIAM Davies 